\title{
Variations in Important Water Quality Parameters and Fish Species in Thondaimanaru Lagoon, Jaffna, Sri Lanka
}

\author{
P. Shobiya*, K. Sivashanthini, S. Sutharshiny, S. Saruga, K. Gunaalan \\ Department of Fisheries, Faculty of Science, University of Jaffna, Sri Lanka.
}

*Email: shobiyaparamasivam@gmail.com

\begin{abstract}
Thondaimanaru lagoon is one of the shallow coastal lagoons in Jaffna peninsula. The current study was conducted to assess the present status of water quality and fish species composition of this lagoon. Water sampling was conducted from July 2016 to December 2016. Nine random samples were collected monthly in order to determine water temperature, $\mathrm{pH}$, salinity, Dissolved Oxygen, Total Dissolved Solids and turbidity. A smarTROLL Multi parameter (Insitu 458389) was used to measure all the parameters except turbidity, which was measured by turbidity meter (2100Q HACH). Random samples of fishes were collected once a month. One-way ANOVA was used to perform statistical analysis. Water temperature, Dissolved Oxygen, salinity, Total Dissolved Solids and turbidity showed significant variations $(\mathrm{p}<0.05)$ whereas $\mathrm{pH}$ value did not show a significant difference ( $\mathrm{p}>0.05$ ) among the months. Chanos chanos, Hemirhamphus sp., Nematalosa nasus, Mugil cephalus, Liza parsia, Oreochromis mossambicus, Arius caelatus and Gerres lucidus were present throughout the study period. Results revealed that the important water quality parameters fluctuated due to seasonal environmental changes where shallow water depth of lagoon, rate of evaporation as well as precipitation had a significant influence on the water quality characteristics.
\end{abstract}

Keywords - Coastal lagoon, Fish species, Thondaimanaru lagoon, Water quality

\section{INTRODUCTION}

Coastal lagoons are the most productive marine ecosystems in the world due to their location between the land and the sea. They serve as nursery and feeding areas for many continental and marine species (Fiandrino et al., 2003). Thondaimanaru lagoon is one of the coastal lagoon in Jaffna peninsula which is a shallow brackish water body. It is ecologically and economically important due to biological diversity, valuable fish species, water birds, and wildlife resources.

Thondaimanaru barrage was constructed in 1953 by department of irrigation in order to prevent the free flow of seawater into lagoon and gradually convert it as a freshwater lake and improve the quality of water and enhance the cultivation and irrigation of its adjacent regions (Chitravadivelu, 1978). Introduction of barrage with sluice gate has an impact on physico - chemical properties of water and fish diversity of lagoon.

Thus the present investigation was undertaken to study the physico - chemical characteristics and distribution of fish diversity of Thondaimanaru lagoon and to evaluate the current ecological status of this lagoon.

\section{LAGOON CHARACTERISTICS}

Thondaimanaru lagoon (Figure 1 ) is located in North coast of Sri Lanka and situated between $80^{\circ} 08^{\prime} \mathrm{E}-80^{\circ} 29^{\prime} \mathrm{E}$ longitudes and $9^{\circ} 34^{\prime} \mathrm{N}-9^{\circ} 49^{\prime} \mathrm{N}$ (Chitravadivelu, 1978). Thondaimanaru lagoon is covered with $75 \mathrm{~km}^{2}$ of surface area and $287 \mathrm{~km}^{2}$ of catchments area (Sivakumar, 2013). The lagoon is shallow and brackish. It directly opens up to the Palk Strait of the Indian Ocean and mouth is naturally opened and closed due to the tidal action.

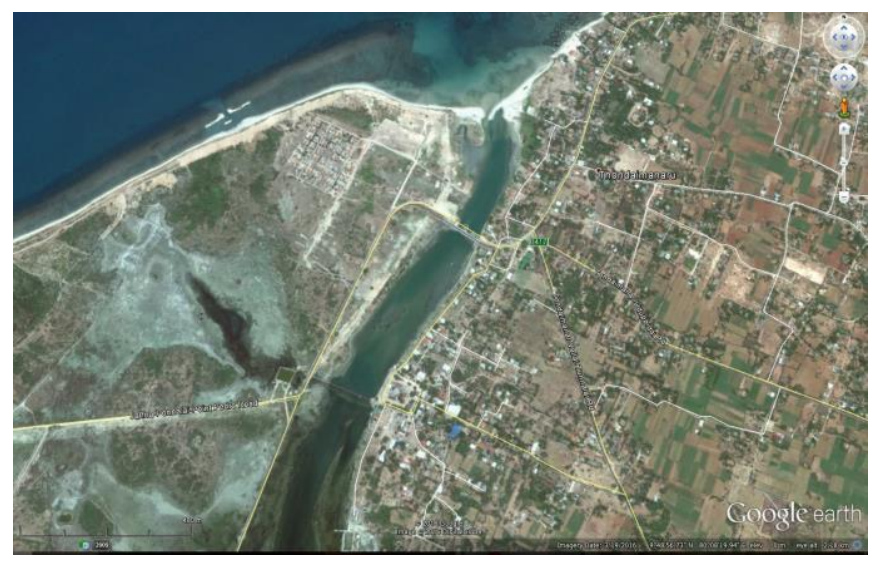

Figure 1: Location map of Thondaimanaru lagoon (Source: Google earth)

\section{MATERIALS AND METHODS}

The current study was carried out in Thondaimanaru lagoon for six months. Nine samples were collected every month from July 2016 to December 2016. Water samples were collected from surface water. All the water samples were analyzed for physico - chemical parameters such as water temperature, $\mathrm{pH}$, salinity, Dissolved Oxygen (DO), Total Dissolved Solids (TDS) and turbidity. Water temperature $\left({ }^{\circ} \mathrm{C}\right), \mathrm{pH}$, salinity (ppt), DO (mg L $\left.{ }^{-1}\right)$ and TDS (ppt) were measured by using smarTROLL Multi parameter (Insitu 458389). Turbidity (Nephelometric Turbidity Units - NTU) was measured by the Turbidity meter (2100Q HACH) with reference to HACH water analysis book. 
Random samples of fishes were collected once a month during the six-month period of study. Hooks and line and simple nets were used to collect the fishes. The fish samples were also collected from the fishermen who are involved fishing in Thondaimanaru lagoon. Randomly collected samples were placed in clear transparent polythene bags and brought to the laboratory. Identification of samples was done up to the species level (Munro, 1995) and photographs of all specimens were taken at the laboratory. In laboratory, fish were identified by using world recognized references (Munro, 1995 \& De Bruin et al., 1995).

\section{STATISTICAL ANALYSIS}

One-way ANOVA (Minitab 2016) was used to compare the collected water quality parameters with different months. Differences between means were considered significant when $\mathrm{p}<0.05$. Results were computed in form of graphs.

\section{RESULTS}

\section{A. Water quality characteristics}

The monthly variation of physico - chemical parameters are shown in Figure 2. Water temperature, DO, salinity, TDS and turbidity showed significant variations $(\mathrm{p}<0.05)$ whereas $\mathrm{pH}$ value showed no significant difference $(p>0.05)$ among the months.

In the present study, the temperature was fluctuated between $26.50{ }^{\circ} \mathrm{C}$ and $31.16^{\circ} \mathrm{C}$. Maximum temperature was recorded in October and minimum in December, 2016. The $\mathrm{pH}$ values varied within a narrow range from 8.33 to 8.55 . Highest mean value of DO was recorded in the month of December $(6.75 \mathrm{mg}$ $\left.\mathrm{L}^{-1}\right)$ and lowest mean value was recorded in the month of October $\left(8.46 \mathrm{mg} \mathrm{L}^{-1}\right)$. The monthly variation of salinity and TDS followed a similar pattern of fluctuations, where maximum value was recorded in the month of October and minimum value in the month of December. The turbidity of Thondaimanaru lagoon water fluctuates from 5.79 NTU to 15.82 NTU.

\section{B. Identification of fish}

Chanos chanos, Hemirhamphus sp., Nematalosa nasus, Mugil cephalus, Liza parsia, Oreochromis mossambicus, Arius caelatus and Gerres lucidus were identified fish species throughout the research period (Table 1).

\section{DISCUSSION}

In the present study, water temperature was increased from July to October and declined from November to December (Figure 2a). This might be the result of high environmental temperature during October and low environmental temperature and run - off during rainy season could be the reasons for decrease in water temperature of the lagoon during November and December. A similar study on lagoon stated that, the difference between the maximum and minimum temperature at the barrage is $4{ }^{\circ} \mathrm{C}$ in February and $6{ }^{\circ} \mathrm{C}$ in July. Rate of evaporation during dry season is $136.9 \mathrm{cu} / \mathrm{sq}$. ft. per 24 hours (Atputhanathan et al., 1968). During this period there is a high rate of mortality of fishes that get trapped in these pools (Atputhanathan et al., 1968). Therefore, the fluctuation in water temperature has a strong influence on survival of fish species in the lagoon.

The $\mathrm{pH}$ of water indicates alkaline value (Figure $2 \mathrm{~b}$ ). These $\mathrm{pH}$ changes may be conducive for fish since they usually live at $\mathrm{pH}$ levels between 6.0 and 9.0, although they may not tolerate a sudden change within this range (Adefemi et al., 2007).

DO value was high in December where the water temperature is low in December (Figure 2c). Babalola and Agbebi, 2013 in their research stated that "during dry season, the dissolved oxygen escaped to the atmosphere from the surface of Kuramo Lagoon water due to high temperature and during the rainy season the dissolved oxygen increased as a result of dissolved atmospheric oxygen from rain water and high wind". When water temperature increases the solubility of oxygen decreases in water.

During the study period from July to October salinity increased and decreased from November and lowest salinity was recorded in the month of December (Figure 2d). It could be as a result of low rainfall and high rates of evaporation between July and October and high level of rainfall and low rate of evaporation in November and December respectively. Atputhanathan et al., 1970 reported that "monthly average salinity in the Thondaimanaru lagoon in 1970 from July to December was $22.5 \mathrm{ppt}$ to $2.25 \mathrm{ppt}$ respectively and also pointed out that salinity was low during wet season and high during dry season". Further the study found out that "the pattern of distributions of flora and fauna were correlated with salinity". Similar trend of fluctuation in salinity was observed in the present study. Although the value of TDS (Figure 2e) of the Thondaimanaru lagoon showed a similar pattern of trend as salinity in the current study and shared the same reason as salinity.

Turbidity results from the scattering and absorption of incident light by particulate matter in the water and can often be related to solids (Chapman et al., 1992). Turbidity fluctuated with months due to presence of solids from run off and soil particles from land based sources in to the lagoon water.

Chitravadivelu found out that "fishes had been reduced from 47 species during 1967 - 1968 to about 15 in 1978 and explained that evaporation of water resulting in the increased salinity to limits must have been the cause for the disappearance of certain species. After the artificial barrier, it became as a closed system and when atmospheric temperature increases water temperature also increases. As a result, water evaporate simultaneously, due to this there may be changes in salinity, DO and other water parameters. Consequently, the system undergoes environmental stress. The candidates of fish which can't tolerate these changes are lost from the lagoon". 

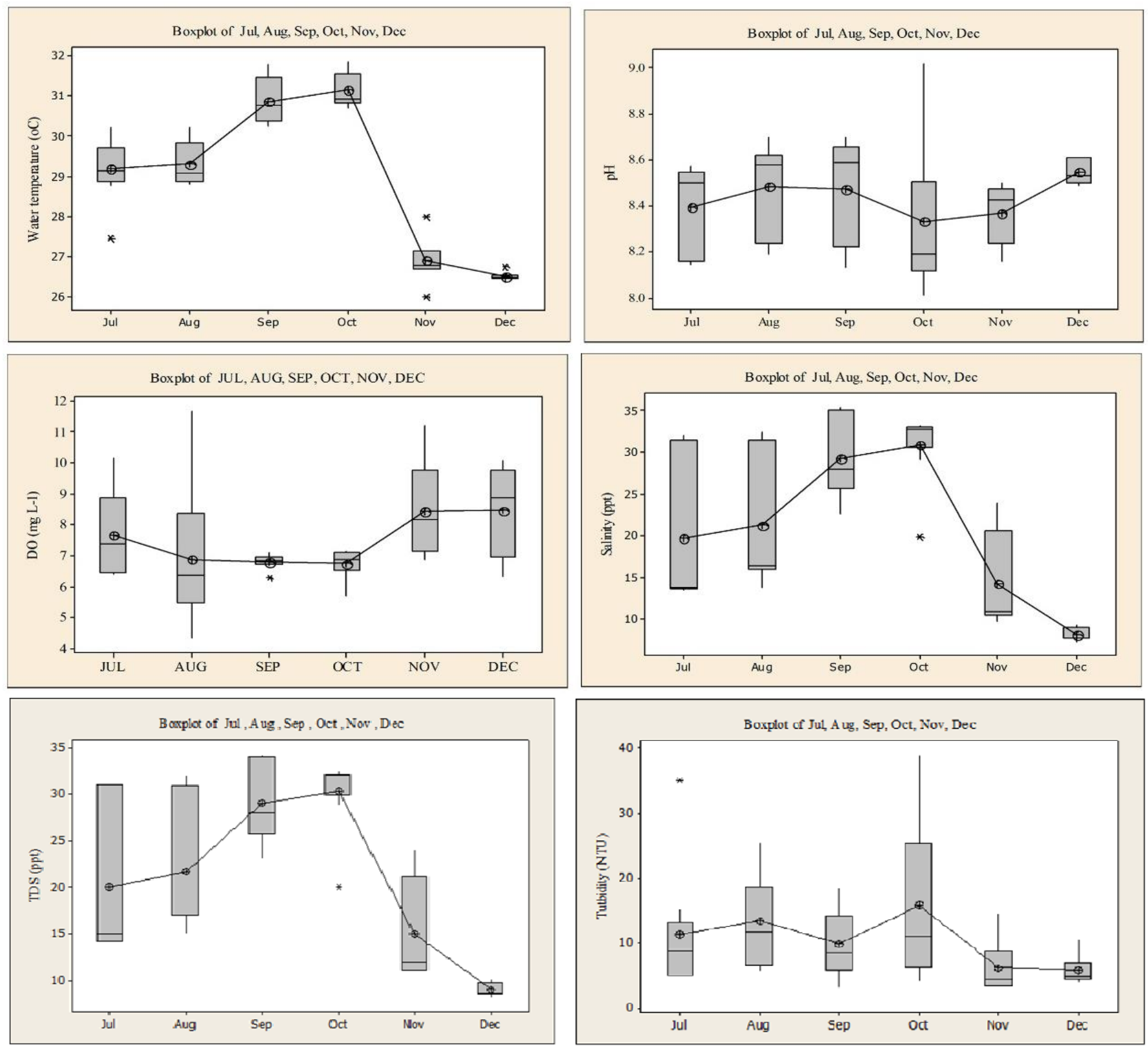

Figure 2: Variations of important water quality parameters in Thondaimanaru lagoon in 2016 : Water temperature (a), pH (b), DO (c), Salinity (d), TDS (e) and Turbidity (f)

In another study Piratheepa et al., 2016 stated that "four species of fish were identified such as Chanos chanos, Hemirhamphus sp., Nematalosa sp. and Mugil cephalus. Lagoon is being subjected to adverse environmental conditions that threaten its fish and shellfish biodiversity due to lack of saline water availability and changes in rainfall pattern. Fluctuation of fish and shellfish were observed during the study period. During the rainy season, species diversity was observed high compared with other months. Main causes for the changes in fish and shellfish composition are absence of water circulation, changes in water depth, salinity and absence of rainfall. After the introduction of the barrage with sluice gate, changes in fish and shellfish were observed due to the increased salinity in dry season". Similar status of diversity of fish was observed in the current study.

\section{CONCLUSION}

Based on the present study it can be pointed out that the important water quality parameters fluctuated due to the seasonal environmental changes. In the shallow water, the rate of evaporation as well as precipitation influence the water quality characteristics. 
Table 1: Identified fish species in Thondaimanaru Lagoon in 2016.

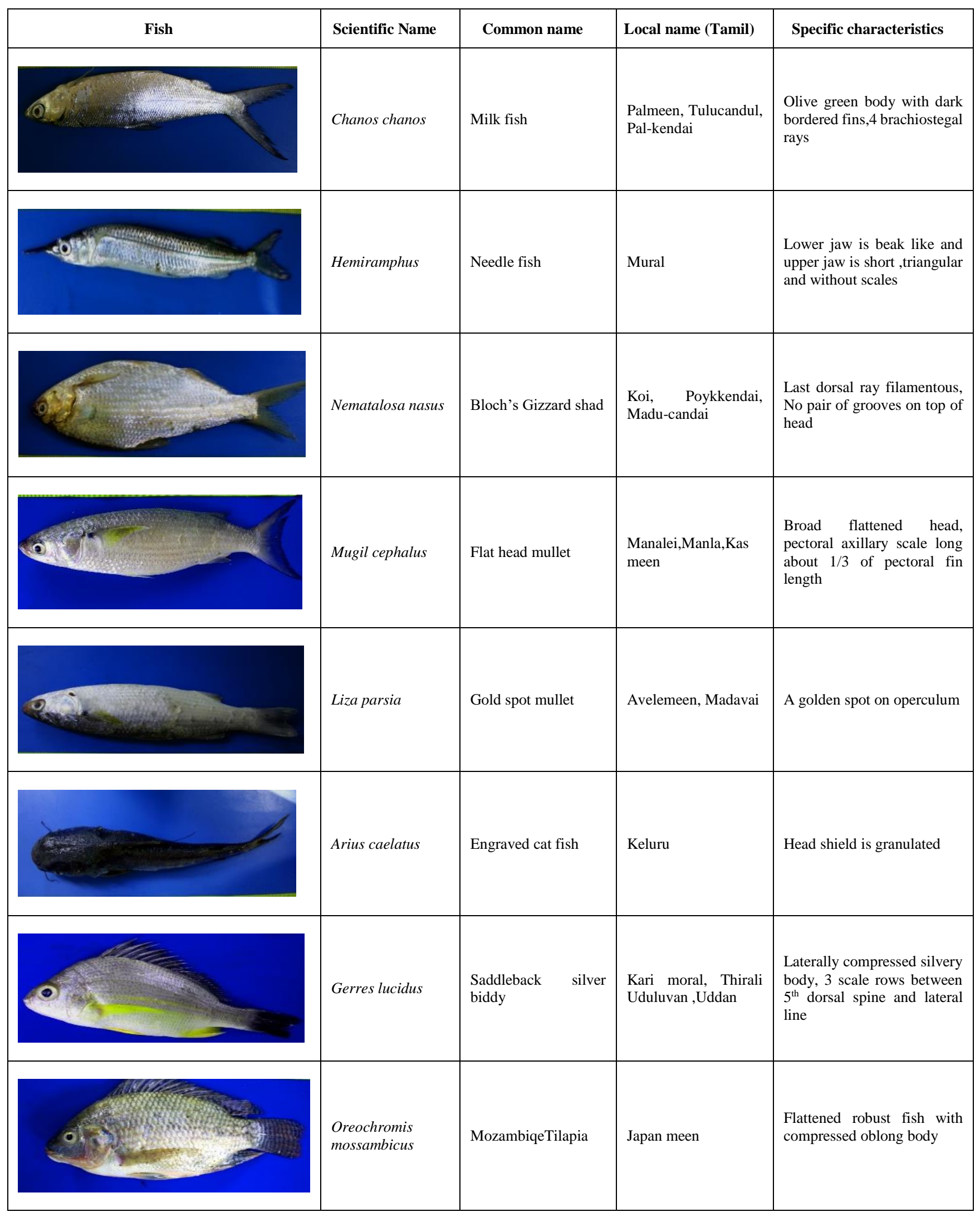




\section{FUTURE CONSIDERATION}

Continuous long term systematic monitoring of physico chemical parameters of lagoon water is needed to conserve the Thondaimanaru lagoon. There is no reliable estimates of sources available regarding loss in fish production or other documentation regarding the lagoon water. Thus there is a potential for researchers and other stakeholders to continue monitoring and analyse the lagoon ecosystem in order to preserve it for future generation.

\section{REFERENCE}

Adefemi, O. S., Asaolu, S. S. and Olaofe, O., (2007). Assessment of the physico-chemical status of water samples from major dams in Ekiti State, Nigeria. Pakistan Journal of Nutrition 6(6), 657 - 659.

Atputhanathan, M. and Chitravadivelu, K., (1968). Fishes of the Thondaimannar lagoon. Proc. Sri Lanka Association of Advancement of Science 25 (1), 68.

Atputhanathan, M. Chitravadivelu, K. Duruvasangary, K. Ponnambalam, V. Selvanayagam, K. Shanmuganathan, K and Sivapathasundaram, K., (1979). Final report of the Hydrological survey of Thondaimannar lagoon $-\mathrm{A}$ component of the National work shop on Science Education to design and develop Innovative science and Technology Curricula based on real life experiences and environment.2.

Babalola, O. A. and Agbebi, F. O., (2013). Physico-Chemical Characteristics and Water Quality Assessment from Kuramo Lagoon, Lagos, Nigeria. Society for Science and Nature 3, 98-102.
Chapman, D. and Kimstach, V., (1992). The selection of water quality variables. Water Quality Assessments: a Guide to the use of Biota, Sediments and Water in environmental monitoring.

Chitravadivelu, K., (1978). Fishery Potentialities of the Thondaimanaru Lagoon and a way of developing it, Field Work Center Newsletter 9, 9 - 13.

De Bruin, G. H. Russell. B. C .and Bogusch, A., (1995). The marine fishery resources of Sri Lanka. Food and Agriculture Organization (FAO).

Fiandrino, A., Martin, Y., Got, P., Bonnefont, J. L. and Troussellier, M.., (2003). Bacterial contamination of Mediterranean coastal seawater as affected by riverine inputs: simulation approach applied to a shellfish breeding area (Thau lagoon, France). Water Research 37(8) 1711-1722.

Munro, I. S. R., (1995). The Marine and freshwater fishes of Ceylon. Department of external affairs, Canberra, Australia.

Piratheepa, S., Rajendramani, G. and Eshwaramohan, T., (2016). Changes in fish and shellfishes in Thondamanaru lagoon, Jaffna, Sri Lanka, Journal of Animal and Vaterinary sciences, 3(6),669-673.

Sivakumar, S. S., (2013). Reclamation of Land and Improve Water Productivity of Jaffna Peninsula of Northern Sri Lanka by Improving the Water Quality of the Lagoons. Research Journal of Science and IT Management 2, 20 - 27. 
